\title{
PEMAHAMAN GURU TERHADAP TINGKAT BERPIKIR SOAL YANG DISUSUN PADA KEAHLIAN TEKNIK BANGUNAN SMK
}

\author{
Isma Sofiana \\ Sutrisno \\ Antelas Eka Winahyo
}

\begin{abstract}
Abstrak: Tujuan penelitian adalah untuk mendeskripsikan tingkat berpikir soal ujian, pemahaman guru tentang tingkat berpikir soal ujian, dan hubungan pengalaman kerja dengan pemahaman guru tentang tingkat berpikir. Teknik pengumpulan data menggunakan angket dan dokumentasi. Teknik analisis data menggunakan statistik deskriptif persentase dan korelasi Product Moment. Hasil penelitian menunjukkan bahwa soal ujian yang dibuat guru terdiri 55,03\% tingkat berpikir mengingat (C1), 23,97\% memahami (C2), 20,28\% aplikasi (C3), dan $0,72 \%$ analisis (C4); pemahaman guru terhadap tingkat berpikir soal ujian yang disusun adalah $\mathrm{C} 1=90,37 \%, \mathrm{C} 2=50,69 \%$, $\mathrm{C} 3=92,11 \%$, dan $\mathrm{C} 4=50,43 \%$; dan terdapat hubungan positif yang signifikan pengalaman kerja dengan pemahaman guru tentang tingkat berpikir soal ujian, dengan $\mathrm{r}=0,48$ dan sig. 1-tailed $=0,00$.
\end{abstract}

Kata-kata Kunci: berpikir, soal, guru

\begin{abstract}
Teachers Understanding on the Level of Thinking on the Examination Prepared for Building Engineering Program of Vocational High School. The study aimed to describe the level of thinking on examination, the teacher's understanding of the level of thinking on examination, and the relationship between work experience and the teacher's understanding of the level of thinking. Data were collected using questionnaires and documentation. Data analysis techniques used a descriptive statistic of percentage and the product moment correlation. The results of the study showed that the test questions made by the teacher consisted of 55.03\% of thinking rate (C1), 23.97\% understanding (C2), 20.28\% application (C3), and $0,72 \%$ analysis (C4); the teachers understanding on the level of thinking on the examination was composed of $C 1=90.37 \%, C 2=50.69 \%, C 3=92.11 \%$, and $C 4=50.43 \%$; and there is a significant positive relationship between work experience and the teacher's understanding of the level of thinking on the examination, with $r=0.48$ and sig. 1 tailed $=0.00$.
\end{abstract}

Keywords: thinking, examination, teacher

$\mathrm{P}$ endidikan adalah usaha sadar untuk menyiapkan peserta didik melalui kegiatan bimbingan, pengajaran, dan latihan sesuai dengan Undang-undang Sistem Pendidikan Nasional No 2 Tahun 1989 (Depdiknas, 1989). Guru yang professio- nal dan kompeten sangat dibutuhkan untuk memenuhi tuntutan perkembangan dunia pendidikan yang semakin maju (Santoso, 2012:1). Guru adalah orang yang bertugas dan berwenang dalam melaksanakan pendidikan dan pengajaran,

Isma Sofiana adalah Alumni Program Studi Pendidikan Teknik Bangunan Jurusan Teknik Sipil Universitas Negeri Malang. Email: Sofiana.isma@yahoo.co.id. Sutrsino dan Antelas Eka Winahyo adalah Dosen Jurusan Teknik Sipil Universitas Negeri Malang. Alamat Kampus: Jl. Semarang No. 5 Malang 65145. 
serta memiliki kompetensi untuk mewujudkan tercapainya tujuan pembelajaran.

Kompetensi yang harus dimiliki oleh seorang guru adalah kemampuan pedagogik, professional, kepribadian, dan sosial. Tenaga pendidik dituntut memiliki kemampuan profesional sebagai guru, serta dapat membuat soal dengan kualitas baik dan memahami dengan benar tingkatan berpikir yang akan digunakan dalam menyusun soal (Susilo, 2011:115). Namun dalam kegiatan belajar-mengajar, berpikir kognitif yang berupa tingkat mengingat, memahami, dan mengaplikasikan adalah yang masih dominan diterapkan di sekolah, sedangkan tingkat menganalisis, mengevaluasi, dan mencipta masih sangat kurang (Arisandi dan Madlazim, 2015:8).

Berdasarkan pengalaman dan hasil supervisi pembelajaran di sekolah, tidak sedikit guru yang lupa terhadap teori tingkat berpikir, bagaimana cara penerapan teori tingkat berpikir tersebut dalam pembelajaran (Alenmarlis, 2014). Hal ini merupakan salah satu penyebab terjadinya salah pengertian antara berpikir kognitif yang ditetapkan oleh guru dengan berpikir kognitif berdasar Bloom. Begitu pula kebanyakan soal yang dibuat oleh guru masih mengukur kemampuan siswa pada tingkatan pengetahuan dan pemahaman saja. Akibatnya soal tidak dapat mengukur ketercapaian tujuan pembelajaran.

Dunia pendidikan memerlukan guru yang professional dan mempunyai kompetensi, karena guru merupakan pemegang peranan utama dalam proses pembelajaran maupun dalam penilaian pembelajaran. Selain itu, dalam pembuatan soal dibutuhkan ketelitian dengan memperhatikan penyebaran tingkatan berpikir pada soal yang dibuat dan kesesuaian tingkat berpikir yang ada pada tujuan pembelajaran yang telah ditetapkan dalam silabus.
Menurut Utari (2013) Taksonomi Bloom adalah struktur hierarki yang mengidentifikasikan skills mulai dari tingkat yang rendah hingga yang tinggi. Bloom membagi domain kemampuan menjadi kognitif, afektif, dan psikomotorik. Diantara ketiga domain itu, domain kognitiflah yang paling banyak dibicarakan oleh para guru disekolah karena berkaitan dengan kemampuan peserta didik dalam menguasai bahan pengajaran yang telah disampaikan oleh guru.

Menurut Sukardjo (1994:18) aspek kognitif meliputi tingkah laku seperti: mengingat, menalar, memecahkan masalah, pembentukan konsep dan batas tertentu berpikir kreatif. Menurut Utari (2013) berpikir kognitif menekankan pada knowledge. Maka berpikir kognitif dapat diartikan berpikir yang mencakup kegiatan berpikir. Dalam berpikir kognitif terdapat tingkatan yang mengarahkan peserta didik untuk berpikir mulai dari tingkat rendah hingga tingkat tinggi.

Perubahan Taksonomi Bloom pada berpikir kognitif yang telah direvisi Anderson dan Krathwohl (2001: 66) adalah berupa kata kunci dari kata benda menjadi kata kerja untuk setiap level taksonomi. Perubahan ini dibuat agar lebih sesuai dengan tujuan pembelajaran. Ada enam tingkatan dalam Bloom Revisi, yaitu tingkat mengingat (remembering) (C1), memahami (understanding) (C2), menerapkan (applying) (C3), menganalisis (analyzing) (C4), menilai (evaluating) (C5), dan mencipta (creating) (C6).

Seorang guru dituntut untuk memahami masing-masing tingkatan berpikir, agar dapat memilah tingkatan berpikir dengan tepat. Seperti yang dikemukakan oleh Susilo (2011:115) tenaga pendidik hendaknya memiliki kemampuan profesional sebagai guru, serta dapat memahami cara membuat soal dengan kualitas tinggi dan memahami dengan benar tingkatan berpikir yang akan digunakan dalam menyusun soal. Diantara variabel 
yang dimungkinkan berpengaruh terhadap pemahaman guru adalah pengalaman kerja. Hasil penelitian Rahmadhani dan Soedjono (2014) menunjukkan bahwa pengalaman kerja memiliki pengaruh terhadap kompetensi kerja dengan nilai korelasi parsial 0,55. Demikian pula hasil penelitian Dwiantik (2014), pengalaman kerja berpengaruh secara signifikan terhadap pemahaman. Akan tetapi hasil penelitian Hartati (2011) menunjukkan tidak ada pengaruh yang signifikan antara pengalaman belajar terhadap prestasi belajar siswa di SMA.

Menurut Muslich (2007:13) bahwa selain pendidikan, pengalaman kerja juga merupakan aspek yang mempengaruhi kualitas profesionalisme guru, salah satu indikator pengalaman kerja adalah masa kerja. Guru yang mempunyai pengalaman kerja yang banyak cenderung memiliki tingkat kualitas pembelajaran yang baik. Oleh karena itu pengalaman merupakan salah satu faktor yang mempengaruhi pemahaman seseorang.

Tujuan dari penelitian ini adalah: (1) mendeskripsikan tingkat berpikir soal ujian akhir semester mata pelajaran produktif dan adaptif Keahlian Teknik Bangunan SMK di Mojokerto, (2) mendeskripsikan pemahaman guru tentang tingkat berpikir soal ujian akhir semester mata pelajaran produktif dan adaptif Keahlian Teknik Bangunan SMK di Mojokerto, dan (3) untuk mengetahui hubungan antara pengalaman kerja dengan pemahaman guru tentang tingkat berpikir soal ujian akhir semester pada mata pelajaran produktif dan adaptif Keahlian Teknik Bangunan SMK di Mojokerto.

\section{METODE}

Penelitian ini menggunakan rancangan penelitian deskriptif dan korelasional. Data penelitian berupa soal-soal ujian berbentuk pilihan ganda. Teknik analisis data yang digunakan dalam penelitian ini adalah deskriptif persentase dan korelasi Pearson Product Moment.

Populasi dalam penelitian ini adalah seluruh guru mata pelajaran produktif dan adaptif di Program Keahlian Teknik Bangunan SMK di Mojokerto beserta soal ujian dan kisi-kisi tingkat berpikir soal ujian yang telah dibuat oleh guru pada semester ganjil tahun ajaran 2015/2016. Sampel dalam penelitian ini adalah sampling jenuh (Nonprobability Sampling), semua anggota populasi digunakan sebagai sampel (Sugiyono, 2012: 85). Sesuai dengan teknik sampling yang digunakan, maka sampel dalam penelitian ini adalah seluruh guru mata pelajaran produktif dan adaptif yang berjumlah 45 guru beserta soal ujian, dan kisi-kisi tingkat berpikir soal. Mata pelajaran produktif yang diambil ada 6 yaitu: Mekanika Teknik, Ukur Tanah, Interior dan Eksterior Bangunan, Rencana Anggaran Biaya, Perangkat Lunak, dan Gambar Teknik. Mata pelajaran adaptif yang diambil ada 8 yaitu: Bahasa Inggris, Matematika, Fisika, IPA, Kimia, IPS, KPPI, dan Kewirausahaan.

Instrumen dalam penelitian ini adalah angket/kuesioner, lembar ceklis soal, dan kisi-kisi-kisi tingkat berpikir. Angket/kuesioner digunakan untuk menggali data variabel pengalaman kerja guru. Lembar ceklist data soal ujian digunakan untuk menggali data soal ujian. Kisi-kisi tingkat berpikir digunakan untuk mengetahui pemahaman guru tentang tingkat berpikir soal ujian. Penelitian ini menggunakan analisis deskriptif persentase, dan uji hipotesis menggunakan korelasi Pearson Product Moment.

\section{HASIL}

Data penelitian ini berupa tingkat berpikir soal ujian akhir semester pada mata pelajaran produktif dan adaptif Keahlian Teknik Bangunan SMK di Mojokerto. Tingkat berpikir soal ujian akhir 
semester yang dianalisis adalah tingkat berpikir kognitif. Jumlah sampel sebanyak 1.479 soal dari 45 guru yang diambil melalui dokumentasi. Persentase data tingkat berpikir soal dilihat Tabel 1.

Tabel 1. Persentase Tingkat Berpikir Soal

\begin{tabular}{lrc}
\hline Tingkat Berpikir & $\begin{array}{c}\text { Jumlah } \\
\text { Butir } \\
\text { Soal }\end{array}$ & $\begin{array}{c}\text { Persen- } \\
\text { tase (\%) }\end{array}$ \\
\hline Mengingat (C1) & 780 & 55,03 \\
Memahami (C2) & 370 & 23,97 \\
Mengaplikasi (C3) & 316 & 20,28 \\
Menganalisis (C4) & 13 & 0,72 \\
Mengevaluasi (C5) & 0 & 0,00 \\
Mencipta (C6) & 0 & 0,00 \\
\hline \multicolumn{1}{c}{ Jumlah } & 1479 & 100,00 \\
\hline
\end{tabular}

Tabel 2. Hasil Pemahaman Guru terhadap Berpikir C1-C4

\begin{tabular}{lrrrr}
\hline $\begin{array}{l}\text { Pemaham- } \\
\text { an terha- } \\
\text { dap Soal }\end{array}$ & $\begin{array}{r}\text { C1 } \\
(\%)\end{array}$ & $\begin{array}{r}\text { C2 } \\
(\%)\end{array}$ & $\begin{array}{r}\text { C3 } \\
(\%)\end{array}$ & $\begin{array}{r}\text { C4 } \\
(\%)\end{array}$ \\
\hline $\begin{array}{l}\text { Pemaham- } \\
\text { an Benar }\end{array}$ & 90,73 & 50,69 & 92,11 & 50,43 \\
$\begin{array}{l}\text { Pemaham- } \\
\text { an Salah }\end{array}$ & 9,27 & 49,31 & 7,89 & 49,57 \\
\hline \begin{tabular}{l} 
Jumlah \\
\hline
\end{tabular} & 100,00 & 100,00 & 100,00 & 100,00 \\
\hline
\end{tabular}

Pada Tabel 1 terlihat dari 1.479 soal terdapat $55,03 \%$ soal berada pada tingkat berpikir mengingat (C1), 23,97\% soal berada pada tingkat berpikir memahami (C2), 20,28\% soal berada pada tingkat mengaplikasi (C3), $0,72 \%$ soal berada pada tingkat menganalisis (C4) dan $0,00 \%$ soal berada pada tingkat berpikir mengevaluasi (C5), dan mencipta (C6). Hal ini menunjukkan bahwa rentangan tingkat berpikir kognitif pada soal ujian berkisaran antara tingkat berpikir mengingat (C1) sampai dengan tingkat berpikir menganalisis (C4), dengan urutan persentase yang tertinggi tingkat berpikir mengingat ( $\mathrm{C} 1)$, kemudian disusul tingkat berpikir memahami (C2), lalu tingkat berpikir mengaplikasi (C3), dan terendah tingkat berpikir menganalisis $(\mathrm{C} 4)$.
Hasil analisis perbandingan kesesuaian tingkat berpikir soal dengan pemahaman guru terhadap tingkat berpikir soal yang dibuat dapat dilihat pada Tabel 2. Tabel 2 menunjukkan bahwa pemahaman yang benar pada tingkat berpikir mengingat (C1) pada soal adalah sebesar $90,73 \%$, sedang pemahaman tingkat berpikir soal yang salah sebesar 9,27\%. Pada tingkat berpikir memahami (C2) diperoleh pemahaman soal benar sebesar $50,69 \%$, sedang pemahaman tingkat berpikir soal yang salah sebesar 49,31\%. Pada tingkat berpikir mengaplikasi (C3) diperoleh pemahaman tingkat berpikir soal yang benar sebesar $92,11 \%$, sedang pemahaman tingkat berpikir soal yang salah sebesar 7,89\%. Pada tingkat berpikir menganalisis $(\mathrm{C} 4)$ diperoleh pemahaman tingkat berpikir soal yang benar sebesar $50,43 \%$, sedang pemahaman tingkat berpikir soal yang salah sebesar $49,57 \%$. Oleh karena itu dapat dinyatakan bahwa pemahaman guru terhadap tingkat berpikir soal ujian yang dibuat adalah pada tingkat berpikir mengingat (C1) masuk kategori baik, pada tingkat berpikir memahami (C2) masuk kategori kurang, pada tingkat berpikir mengaplikasi (C3) masuk kategori baik, dan pada tingkat berpikir menganalisis (C4) masuk kategori kurang paham.

Tabel 3. Hasil Uji Normalitas

\begin{tabular}{lllll}
\hline No. & & $\begin{array}{c}\text { Kolmogorov } \\
\text {-Smirnov }\end{array}$ & Df & Sig. \\
\hline 1 & $\begin{array}{l}\text { Pengalaman } \\
\text { Kerja Guru } \\
2\end{array}$ & 0,125 & 45 & 0,077 \\
$\begin{array}{l}\text { Pemahaman } \\
\text { Tingkat } \\
\text { Berpikir } \\
\text { Soal }\end{array}$ & 0,114 & 45 & 0,173 \\
\hline
\end{tabular}

Sebelum dilaksanakan pengujian hipotesis, dilakukan beberapa uji persyaratan analisis. Uji prasyarat ini dilakukan agar kesimpulan hasil analisis yang didapatkan tidak menyimpang dari kondisi yang sebenarnya. Uji prasyarat analisis dalam penelitian ini meliputi uji norma- 
litas dan uji linieritas. Uji Normalitas dilakukan dengan menggunakan uji $\mathrm{Kol}$ mogorov-Smirnov menggunakan taraf signifikansi 5,00\%. Hasil uji normalitas terhadap variabel pengalaman kerja guru dan pemahaman tingkat berpikir soal terlihat pada Tabel 3.

Berdasarkan hasil uji normalitas Tabel 3, sebaran data variabel pengalaman kerja guru dan pemahaman tingkat berpikir soal setelah didapatkan nilai masing-masing residualnya menunjukkan Kolmogorov-Smirnov pengalaman kerja guru sebesar 0,125 dengan harga signifikansi hasilnya $0,077>0,05$ dan pemahaman tingkat berpikir soal sebesar 0,114 dengan harga signifikansi hasilnya 0,173 $>0,05$. Untuk kedua variabel didapatkan harga sig >0,05, maka dapat dinyatakan bahwa data ini berdistribusi normal artinya data yang telah digunakan sudah telah sesuai dengan populasi yang berdistribusi normal, sehingga data tersebut memenuhi persyaratan distribusinya.

Uji Linieritas dimaksudkan untuk menguji linier atau tidaknya data yang dianalis dengan menggunakan taraf signifikansi 5,00\%. Hasil uji linieritas terhadap variabel pengalaman kerja guru dan pemahaman tingkat berpikir soal dengan menggunakan bantuan program SPSS for windows adalah sebagai berikut.

Berdasar Tabel 4, hasil uji linieritas antara pengalaman kerja guru dengan pemahaman tingkat berpikir soal pada hasil Deviation from Linearity menunjukkan $\mathrm{F}$ $=1,943$ dengan nilai signifikansi sebesar $0,064$ ( $p>0,05)$. Dengan demikian dapat dinyatakan bahwa hubungan antara pengalaman kerja guru dengan pemahaman tingkat berpikir soal tersebut adalah linier.

Pengujian hipotesis merupakan prosedur yang digunakan untuk memperoleh keputusan apakah hipotesis yang telah dirumuskan tersebut diterima atau ditolak. Rumusan dari hipotesis penelitian ini adalah ada hubungan positif yang signifikan antara pengalaman kerja dengan pemahaman guru tentang tingkat berpikir soal ujian akhir semester pada mata pelajaran produktif dan adaptif Keahlian Teknik Bangunan SMK di Mojokerto.

Hipotesis tersebut dianalisis menggunakan korelasi Pearson Product Moment. Hasil analisis hubungan antara variabel pengalaman kerja guru dengan pemahaman guru tentang tingkat berpikir soal dapat dilihat pada Tabel 5 .

Tabel 4. Hasil Uji Linieritas

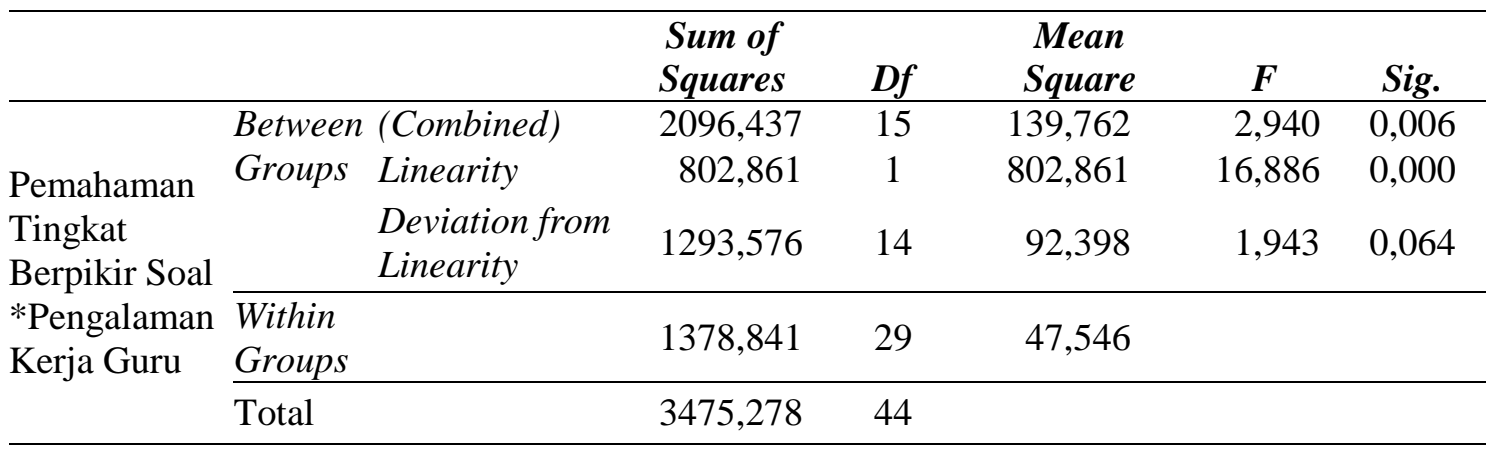

Tabel 5. Hubungan Pengalaman Kerja Guru dengan Pemahaman Tingkat Berpikir Soal

\begin{tabular}{llcc}
\hline & \multicolumn{2}{c}{ Pengalaman Kerja Guru } & Pemahaman Guru \\
\hline Pengalaman Kerja Guru & Pearson Correlation & 1,000 & 0,481 \\
& Sig. (1-tailed) & & 0,000 \\
& $\mathrm{~N}$ & 45,000 & 45,000 \\
Pemahaman Guru & Pearson Correlation & 0,481 & 1,000 \\
& Sig. (1-tailed) & 0,000 & \\
& $\mathrm{~N}$ & 45,000 & 45,000 \\
\hline
\end{tabular}


Berdasar Tabel 5, hasil analisis korelasi Pearson Product Moment yang telah dilakukan, didapatkan nilai korelasi $(\mathrm{r})=$ 0,48 dengan nilai signifikansi $\mathrm{p}(0,00)<$ 0,05 . Oleh karena itu dapat dinyatakan bahwa ada hubungan positif yang signifikan pengalaman kerja guru dengan pemahaman guru tentang tingkat berpikir soal ujian akhir semester.

\section{PEMBAHASAN}

Berdasarkan hasil yang diperoleh dalam penelitian ini yaitu perolehan persentase tingkat berpikir pada soal terdiri $55,03 \%$ (C1), 23,97\% (C2), 20,28\% (C3), $0,72 \%$ (C4), $0 \%$ (C5), dan 0\% (C6). Hal ini dapat diketahui bahwa rentangan tingkat berpikir kognitif pada soal ujian berkisaran antara tingkat berpikir mengingat (C1) sampai dengan tingkat berpikir menganalisis (C4), dengan urutan persentase yang tertinggi tingkat berpikir mengingat (C1), kemudian disusul tingkat berpikir memahami (C2), lalu tingkat berpikir mengaplikasi (C3), dan terendah tingkat berpikir menganalisis (C4). Tingkat berpikir kognitif soal ujian pada tingkat berpikir mengingat (C1), tingkat berpikir memahami (C2), dan tingkat berpikir mengaplikasi (C3) yang masih dominan diterapkan, tingkat berpikir menganalisis (C4) masih terlalu kecil, sedangkan tingkat berpikir mengevaluasi (C5), dan tingkat berpikir mencipta (C6) tidak tersedia.

Hasil penelitian ini tidak jauh berbeda dengan hasil penelitian yang dilakukan oleh Maghviroh dan Sutrisno (2016) bahwa tingkat berpikir soal ujian akhir semester bentuk pilihan ganda pada mata pelajaran adaptif, normatif, dan produktif yang dibuat oleh guru pada Kompetensi Keahlian Teknik Gambar Bangunan di SMK Negeri 6 Kota Malang masih didominasi oleh berpikir tingkat rendah, pada tingkat pengetahuan dan pemahaman terlalu besar. Tingkat aplikasi dan analisis terlalu kecil. Tingkat evaluasi dan kreativitas tidak tersedia. Demikian pula sesuai dengan hasil penelitian A'yun dan Sutrisno (2017) yang menunjukkan bahwa hasil penelitian menunjukkan proporsi soal ujian tingkat berpikir mengingat (C1) 37,00\%, memahami (C2) 33,00\%, dan aplikasi (C3) 42,00\%, sedang tingkat analisis (C4), evaluasi (C5), dan mencipta (C6) $0,00 \%$.

Berdasarkan hasil penelitian yang diperoleh dalam penelitian ini bahwa pada tingkat berpikir mengingat $(\mathrm{C} 1)$ diperoleh pemahaman guru terhadap soal menunjukkan benar sebesar $90,73 \%$ dan pemahaman soal salah sebesar 9,27\%. Berdasarkan perbandingan $90,73 \%$ dengan $9,27 \%$, maka guru dapat dikatakan paham dengan berpikir Bloom. Pada tingkat berpikir memahami (C2) diperoleh pemahaman guru terhadap soal menunjukkan benar sebesar 50,69\% dan pemahaman soal salah sebesar $49,31 \%$. Berdasarkan perbandingan $50,69 \%$ dengan 49,31\%, maka guru dapat dikatakan kurang paham dengan berpikir Bloom, sebab terdapat hampir 50,00\% pemahaman soal salah. Pada tingkat berpikir mengaplikasi (C3) diperoleh pemahaman guru terhadap soal menujukkan benar sebesar $92,11 \%$ dan pemahaman soal salah sebesar $7,89 \%$. Berdasarkan perbandingan $92,11 \%$ dengan $7,89 \%$, maka guru dapat dikatakan guru telah paham dengan berpikir Bloom. Pada tingkat berpikir menganalisis (C4) diperoleh pemahaman guru terhadap soal menunjukkan benar sebesar $50,43 \%$ dan pemahaman soal salah sebesar $49,57 \%$. Berdasarkan perbandingan $50,43 \%$ dengan $49,57 \%$, maka guru dapat dikatakan kurang paham dengan berpikir Bloom, sebab hampir $50,00 \%$ pemahaman soal salah.

Hasil penelitian ini tidak jauh berbeda dengan hasil penelitian yang dilakukan oleh Rahayu, dkk. (2014:39-43) bahwa terjadi salah pengertian atau kesalah pahaman guru terhadap teori 
tingkat berpikir yang telah dipahaminya dengan teori tingkat berpikir menurut Bloom, karena dari 40 butir soal pilihan ganda buatan guru pada mata pelajaran ekonomi siswa kelas X di SMA Negeri 5 Jember, terdapat 22 soal yang tidak sesuai antara berpikir kognitif yang ditetapkan oleh guru dengan berpikir kognitif menurut Bloom.

Seperti yang dikemukakan oleh Nuraida (2012) penetapan berpikir masih banyak membingungkan bagi para guru, sehingga diperlukan pelatihan yang membahas secara khusus mengenai sistem penilaian secara tuntas. Hal yang sama dikemukakan oleh Alenmarlis (2014) berdasarkan pengalaman dan hasil supervisi pembelajaran di sekolah, tidak sedikit guru yang lupa terhadap teori tingkat berpikir, bagaimana cara penerapan teori tingkat berpikir tersebut dalam pembelajaran, dan dalam administrasi pembelajaran penetapan berpikir yang akan diukur pencapaiannya, ternyata tidak nyambung dengan kenyataan yang terjadi dalam pelaksanaan proses pembelajaran. Oleh karena itu dapat dinyatakan bahwa pemahaman guru terhadap tingkat berpikir soal masih rendah, ada yang lupa tentang teori tingkat berpikir sehingga terjadi salah pengertian antara berpikir kognitif yang ditetapkan oleh guru dengan berpikir kognitif berdasar Taksonomi Bloom.

Berdasarkan uraian di atas dapat ditarik kesimpulan bahwa guru sudah memahami penerapan tingkat berpikir yang sesuai dengan Taksonomi Bloom yaitu pada tingkat berpikir mengingat $(\mathrm{C} 1)$ dan tingkat berpikir mengaplikasi (C3) dalam penyusunan soal mata pelajaran produktif dan adaptif. Akan tetapi, masih belum memahami pada tingkat berpikir memahami (C2) dan tingkat berpikir menganalisis (C4) dalam penerapannya pada penyusunan soal.
Berdasarkan hasil yang diperoleh pada analisis hasil penelitian maka dapat dinyatakan pengalaman kerja guru memiliki hubungan yang signifikan dengan pemahaman guru tentang tingkat berpikir soal ujian akhir semester pada mata pelajaran produktif dan adaptif di Keahlian Teknik Bangunan SMK di Mojokerto. Artinya makin tinggi pengalaman kerja guru, maka akan makin tinggi pula pemahaman guru tentang tingkat berpikir soal ujian tersebut. Nilai kontribusi dari variabel pengalaman kerja guru terhadap variabel pemahaman guru tentang tingkat berpikir soal ujian sebesar $23,14 \%$ yang ditentukan pada hasil perkalian kuadrat Pearson Correlation dikalikan dengan persentase. Sisa nilai kontribusi dari variabel pengalaman kerja guru sebesar $76,86 \%$ disebabkan oleh variabel lain yang tidak dicari dalam penelitian ini.

Hasil penelitian ini tidak jauh berbeda dengan hasil penelitian yang dilakukan oleh Hidayahni (2015) berdasarkan hasil analisis hubungan antara pengalaman mengajar dengan kompetensi pedagogik guru akutansi memiliki hubungan positif dan signifikansi, dan korelasi antara variabel pengalaman mengajar dengan kompetensi pedagogik guru akutansi termasuk dalam kategori rendah dengan nilai yang diperoleh $\mathrm{r}_{\mathrm{xy}}=0,399$ dan signifikansi $<0,05$. Demikian pula Hasil penelitian Rahmadhani dan Soedjono (2014) yang menunjukkan bahwa pengalaman kerja memiliki pengaruh terhadap kompetensi kerja dengan nilai korelasi parsial 0,55. Hasil penelitian Dwiantik (2014), pengalaman kerja berpengaruh secara signifikan terhadap pemahaman. Dengan demikian dapat dinyatakan bahwa hubungan antara pengalaman mengajar dan pemahaman guru umumnya dikategorikan memiliki hubungan positif signifikan.

Seperti juga yang dikemukakan oleh Uno (2011:64) menyatakan kompetensi 
guru tidak dapat berdiri sendiri, tetapi dipengaruhi oleh faktor latar belakang pendidikan, pengalaman mengajar, dan lamanya mengajar. Hal yang sama juga dikemukakan oleh Mulyawan (2012) pengalaman dalam pelatihan menjadi faktor yang paling besar mempengaruhi profesionalisme guru bidang studi, maka guru bidang studi dapat memanfaatkan waktunya semaksimal mungkin untuk menambah pengetahuan dan keterampilan melalui pelatihan. Faktor-faktor lain selain pengalaman kerja yang memengaruhi pemahaman adalah latar belakang pendidikan, penataran dan pelatihan, etos kerja, usia, itelegensi, sedangkan faktor eksternal meliputi: lingkungan kerja, lingkungan sosial budaya dan ekonomi, infomasi (Notoatmodjo, 2003: 120). Maka dapat diketahui bahwa pengalaman kerja guru mempengaruhi pemahaman guru, karena guru yang mempunyai pengalaman kerja yang banyak akan memiliki tingkat kualitas pembelajaran yang baik dan pemahaman yang dimiliki akan makin meningkat.

Berdasarkan uraian di atas dapat ditarik kesimpulan bahwa semakin lama guru mengajar semakin bertambah pula ilmu yang dimilikinya. Semakin banyak pengalaman bermanfaat yang dimiliki seorang guru maka akan berpengaruh terhadap kompetensi profesional guru tersebut. Jadi guru dapat memanfaatkan waktunya dalam pelatihan/penataran semaksimal mungkin, saling bertukar informasi yang dimiliki dengan peserta lain untuk menambah pengetahuan dan keterampilan, karena pengalaman yang dimilikinya dapat dijadikan sebagai bahan acuan selama guru menjalankan tugas sebagai guru. Dengan adanya pengalaman mengajar diharapkan guru mampu berkembang sesuai dengan perkembangan zaman, sebab guru senantiasa dituntut untuk menyesuaikan ilmu dan keterampilannya dengan ilmu dan teknologi yang sedang berkembang saat ini.

\section{SIMPULAN DAN SARAN}

Berdasarkan hasil dari pembahasan di atas dapat disimpulkan sebagai berikut. (1) Soal-soal ujian akhir semester yang dibuat guru pada mata pelajaran produktif dan adaptif di Keahlian Teknik Bangunan SMK terdiri 55,03\% soal tingkat berpikir mengingat (C1), 23,97\% soal tingkat berpikir memahami (C2), 20,28\% soal tingkat mengaplikasi (C3), 0,72\% soal tingkat menganalisis (C4), $0,00 \%$ soal tingkat berpikir mengevaluasi (C5), dan $0,00 \%$ soal tingkat berpikir mencipta (C6). (2) Pemahaman guru terhadap soal ujian akhir semester yang disusun pada mata pelajaran produktif dan adaptif di Keahlian Teknik Bangunan SMK adalah tingkat berpikir mengingat (C1) sebesar 90,73\%, tingkat berpikir memahami (C2) sebesar 50,69\%, tingkat berpikir mengaplikasi (C3) sebesar 92,11\%, dan tingkat berpikir menganalisis (C4) sebesar $50,43 \%$. (3) Terdapat hubungan positif yang signifikan pengalaman kerja dengan pemahaman guru tentang tingkat berpikir soal ujian akhir semester mata pelajaran produktif dan adaptif di Keahlian Teknik Bangunan Sekolah Menengah Kejuruan.

Berdasarkan kesimpulan di atas, maka saran yang diajukan sebagai berikut. (1) Diharapkan guru melakukan koordinasi bersama dalam setiap penyusunan soal, dan lebih meningkatkan kemampuan pemahaman tingkat berpikir serta implementasinya pada setiap soal yang dibuat, agar soal tersebut mampu mengukur ketercapaian tujuan pembelajaran dengan baik. (2) Diharapkan kepala sekolah lebih memfasilitasi guru untuk mengikuti pelatihan/penataran mengenai tingkat berpikir, guna lebih meningkatkan kemampuan penerapan implementasi tingkat berpikir soal dalam penyusunan soal. (3) Diharapkan dapat dijadikan masukan bagi peneliti selanjutnya untuk melakukan penelitian yang sama dengan pengembangan variabel, sub variabel dan indikator lainnya, karena masih banyak 
faktor-faktor lain yang mempengaruhi pemahaman guru tentang tingkat berpikir soal.

\section{DAFTAR RUJUKAN}

A'yun, N.Q. \& Sutrisno. 2017. Kesesuaian Tingkat Berpikir Soal Ujian dengan Tujuan Pembelajaran pada Keahlian Teknik Gambar Bangunan Sekolah Menengah Kejuruan. Jurnal Bangunan, 22(2): 67-74.

Alenmarlis. 2014. Mengingat dan Memahami Kembali tentang Teori Taksonomi Bloom. (Online), (https:// alenmarlissmpn1gresik.wordpress.co m, diakses 10 Februari 2016).

Anderson, L.W. \& Krathwohl, D.R. 2001. A Taxonomy for Learning, Teaching, and Assesing: A Revision of Bloom's Taxonomy of Educatioanl Objectives. New York: Addison Wesley Longman, Inc.

Arisandi, S.D. \& Madlazim. 2015. Pengembangan Perangkat Pembelajaran yang Mengintegrasikan Berpikir Kognitif, Berpikir Afektif, dan Ranah Psikomotor pada hukum Ohm. Jurnal Inovasi Pendidikan Fisika, 4(3): 7-11. (Online), (https:// ejournal.unesa.ac.id, diakses September 2015).

Depdiknas. 1989. Undang-undang Republik Indonesia Nomor 2 Tahun 1989, tentang Sistem Pendidikan Nasional. (Online), (http://hukum.unsrat.ac.id/ uu/uu_2_89.html, diakses 18 April 2016).

Dwiantik, N. 2014. Pengaruh Pendidikan dan Pengalaman Kerja terhadap Pemahaman Aparatur Pemerintah Mengenai Penerapan Prinsip Akuntabilitas. Skripsi tidak diterbitkan. Bandar Lampung: Universitas Lampung.

Hartati, S. 2011. Pengaruh Pengalaman Belajar terhadap Prestasi Belajar Siswa pada Mata Pelajaran Ekono- mi di Sekolah Menengah Atas Negeri 2 Tambusai Utara. Skripsi tidak diterbitkan. Pekanbaru: Universitas Islam Negeri Sultan Syarif Kasim Riau.

Hidayahni, N. 2015. Hubungan Pengalaman Mengajar dengan Kompetensi Pedagogik Guru Mata Pelajaran Akutansi SMK di Kota Surakarta Tahun 2014/2015. Skripsi tidak diterbitkan. Surakarta: Universitas Sebelas Maret.

Maghviroh, L. \& Sutrisno, S. 2016. Analisis Soal yang Dibuat oleh Guru pada Kompetensi Keahlian Teknik Gambar Bangunan di SMK Negeri 6 Malang. Jurnal Teknologi dan Kejuruan, 39(1): 21-32.

Mulyawan, B. 2012. Pengaruh Pengalaman dalam Pelatihan terhadap Peningkatan Kompetensi Profesional Guru. Jurnal Ilmiah Ilmu Sosial, 11(1): 45--64. (Online), (http://http:// ejournal.undiksha.ac.id, diakses 8 Oktober 2016).

Muslich, M. 2007. Sertifikasi Guru Menuju Profesionalisme Pendidik. Jakarta: Bumi Aksara.

Notoatmodjo, S. 2003. Pengembangan Sumber Daya Manusia. Jakarta: Rineka Cipta.

Nuraida, N. 2012. Sejauh Mana Guru Memahami Ranah Taksonomi Bloom?, (Online), (http://www.kompasiana.com/nunung_nuraida/sejauhmana-guru-memahami-ranah-taksonomibloom, diakses 27 September 2016).

Rahayu, T.D., Purnomo, B.H., \& Sukidin, S. 2014. Analisis Tingkat Kesukaran dan Daya Beda pada Soal Ujian Tengah Semester Ganjil Bentuk Pilihan Ganda Mata Pelajaran Ekonomi Kelas X di SMA Negeri 5 Jember Tahun Ajaran 2012-2013. Jurnal Edukasi UNEJ, 1(1): 39-43. (Online), (https://jurnal.unej.ac.id, diakses 29 Januari 20016). 
Rahmadhani, R. \& Soedjono. 2014. Pengaruh Pelatihan, Pengembangan dan Pengalaman Kerja terhadap Kompetensi Guru. Jurnal Ilmu \& Riset Manajemen, 3(6): 1-15.

Santoso, A. 2012. Kompetensi Guru Pendidikan Agama Islam dalam Pelaksanaan Evaluasi Pembelajaran di SMK Negeri 2 Salatiga Tahun 2011/2012. Skripsi tidak diterbitkan. Salatiga: STAIN Salatiga.

Sugiyono. 2012. Metode Penelitian Kuantitatif, Kualitatif dan $R \& D$. Bandung: Alfabeta.
Sukardjo. 1994. Pengukuran Hasil Belajar Kimia. Yogyakarta: FPMIPA IKIP Jogjakarta.

Susilo, H. 2011. Lesson Studi Berbasis Sekolah: Guru Konservatif Menuju Guru Inovatif. Malang: Bayumedia.

Uno, H.B. 2011. Profesi Kependidikan. Jakarta: Bumi Aksara.

Utari, R. 2013. Taksonomi Bloom Apa dan Bagaimana Menggunakannya? (Online), (http://www.slideshare. net/userdar/766-1-taksonomi-bloomretnookmima, diakses 10 Juni 2013). 